Pakistan Journal of Humanities and Social Sciences

April - June 2018, Volume 6, No. 2, Pages 188 - 204

\title{
Residential Quality of Inner-City of a Traditional Town in Southwestern Nigeria
}

\author{
Adewale Olufunlola YOADE ${ }^{1}$ and Rebecca Olawunmi YOADE \\ ${ }^{1 \& 2}$ Department of Urban and Regional Planning, Wesley University Ondo, Nigeria \\ *E-mail: yoadewale@yahoo.com
}

\begin{abstract}
This study investigates the socio-economic background of inhabitants of the inner-city of a traditional town in Southwestern Nigeria. The paper highlights survey on high density area of Ondo. Both primary and secondary data were utilized for the study. There are twelve (12) political wards in the study area out of which five (5) political wards fall under areas covered by the core. However, three wards were selected and these political wards became the sample frame. Systematic sampling technique was used in selecting residents to be sampled. The first building was chosen randomly. Subsequent unit of investigation was every 10th residential building in each ward. Therefore, a total of 196 copies of questionnaires were administered out of which all copies were retrieved for the study. Sources of secondary data included maps from Planning Office, journals, conference proceedings, unpublished thesis and books. Data collected were analyzed using Statistical Package for the Social Sciences version 23. Both descriptive and inferential tools were used to analyze the data collected. Findings revealed that environmental variables are significantly associated to the condition of the wellness of inhabitants in the area. The paper recommends some policy guidelines, including total demolition (in some parts of the area), rehabilitation and delivery of fundamental infrastructures and services. The study also recommends that both government and nongovernmental agencies to take driving involvement in the upgrading strategy especially in the area of enlightenment and financial backing.
\end{abstract}

Keywords: Inner-city; environment; residential quality; physical condition; infrastructural facilities

\section{Introduction}

Urbanization in the world, especially in developing countries, over the past halfcentury has been accompanied by excessive high level of concentration of urban population in every large city (Un-Habitat, 2003; UN-Habitat, 2012). Urbanization is taking place at 
different speeds in different continents with varying rates in developed and developing countries (World Bank, 2014). Developed countries are urbanized at a relatively leisure rate. For instance, the rate of urbanization in the United States was $40 \%$ in 1930, 70\% in 1960 while it was 75\% + in 1990 (Cities Alliance, 2013; United Nations, 2013).

Mabogunje (2002) established that inhabitants of urban areas in Nigeria in the year 1950 were not up to $15 \%$ of the population. By 1975 , this portion had risen to $23.4 \%$ and by 2000 was $45.3 \%$. According to Mabogunje (2002), the rate of growth of urban population is $4.8 \%$ annually; marked higher than growth rate at $12 \%$ in countries which are developed (HDR, 2004; FRN, 2013). Inversely, other school of thought believe that urbanization is not about the society volume, but must fulfill certain conditions like innovation, physical and economic expansion as well as the diversity in occupation (Harvey, 2000 World Bank, 2013; Dimuna and Omatsone, 2010; Oyeleye 2013). Also, Onibokun (1985) established that modest lodging is the right of every human being, but a large percentage of Nigerians resides in deficient housing, most of which are situated in unworthy environments. Sufficient salubrious livable domiciles, neat surroundings of least acceptable touchstones of spaces and environs with basic amenities are especially wanting in inner-city of towns and cities in Nigeria. Where these amenities are accessible, they are either outdated or inferior or insufficient (Jagun, 1983; Owoeye and Omole, 2012; Zhai and Ng, 2013).

Inner-city component of the urban populace is actually destitute, and is encumbered to finite, inadequate, overfilled and untidy shelter and a generally debased habitat. The deprived urban residents of these areas are subjected to a life characterized by precarious conditions of environmental hazard, health risk, little or poor material possessions (Mabogunje, 1980). Osuide and Dimuna (2005) noted that the process of urbanization in innumerable third world nations especially Nigeria, has not been accompanied with a compatible development of enough residence, cardinal comforts and infrastructures. These have created demand on housing commodities giving rise to huge rents, concentration and growth of ghetto areas (Onibokun, 1972; Olotuah, 2005) and also have consequential influence on the constructed habitat and great implications on the wellness of city dwellers.

Furthermore, Greed (2011) noticed the same style of cities centers' restriction in the United Kingdom and noted that the inner core area has been an utmost planning issue in current years and this has been accompanied by an uninterrupted convey with urban renewal and regeneration of improvised areas (Arimah and Adeagbo, 2000; Fourchard, Albert and Agbola, 2003; Tomori, 2012; UNDESA, 2012). However, beyond the obvious source of these 
recent challenges, every developmental planner has often considered these as menace to planning efforts. Furthermore, it is in the light of this that Jeffrey and Pounder (2004) argued that good physical and environmental state of a place will always foment the physical renewal of the vast location (Yoade, Adeyemi and Onifade, 2018). However, the inner-city neighbourhood of most towns and cities in Sub-Saharan Africa are not properly planned (if planned at all), often characterized by deplorable condition and degraded environments. It is on this note that the study examined residential quality of the inner-city of Ondo, Nigeria.

\section{Literature Review}

The quality of the environment in most city centers in Sub-Sahara Africa is in unworthy condition. This is so much dependent not only on the material components of the buildings (Mabogunje, 1980) but also on their organization as spatial units. Also, the decelerating process of urban planning and zoning has resulted in poor layout of buildings, inadequate drainage systems and lack of refuse elimination amenities. Therefore, there is a high occurrence of pollution (water, land and noise) and environmental problems in the area. Studies have established the unworthy state of urban housing in Nigeria. For example, Onibokun, 1972; Onibokun 1986; Olotuah, 2005; Jagun, 2003; Yoade, Adeyemi and Onifade, 2018 cited that $75 \%$ of the housing units in Nigeria's urban centers are of low quality and the dwellings are located in the core areas (UN-Habitat, 2003). Thus, the outcome of such comparatively excessive rates of urban development and insufficient planning is hazardous, which is evident mostly in housing shortage, insufficient and overexploited social infrastructure and amenities (water, electricity, housing, amongst others), and its peculiar challenge of slum area formation at the inner-city of most towns and cities (Adedeji, 2008; Buys and Miller, 2012; Yoade, Olayiwola and Popoola, 2013).

Ebong (1983) admitted that aesthetics, ornamentation, sanitation, drainage, age of building, access to basic housing facilities, burglary, spatial adequacy, noise level within locality, sewage and waste disposal, air pollution and easiness of movement among others are pertinent quality determinants of a good environment. Also, Afon (2000) stated that environmental conditions in inner cities have gradually degenerated, owing to the rapid growth of the cities and the attendant problems of social services and infrastructures to keep pace with the rate of development. Environment challenges linked with the escalated development of urban slums including overcrowding in sordid housing situations, poor quality or unavailability of basic facilities and social services, such as water and sewage 
facilities and even lack of access routes (Agbola, 1998; UN-Habitat, 2008; Yoade and Adeyemi, 2014; Yoade and Fatusin, 2016).

However, brisk urbanization, especially the growth of big cities and the attached challenges of joblessness, impoverishment, inadequate health facilities, poor sanitation, urban slums and environmental deterioration pose a formidable challenge in many third world countries. Available statistical data reveal that over half of the world's population resides in urban centers, concentrated into three percent of the earth's land area (UNFPA, 1993). However, there are limited studies which have tried to examine residential quality of innercities in Nigeria. The study also examined level of satisfaction with residential quality in the study area. This study thence attempts to bridge this gap in this field of knowledge (Owoeye and Sogbon, 2012a; Awolusi and Jegede, 2013).

Several approaches have been used to explicate the surroundings of urban areas. Among these approaches which are both descriptive and quantitative in nature are the Burgess (1925) Concentric Zones Models, Hoyt's (1939) Sector Model; and Ullman's (1945) Multiple Nuclei Model. These three models are described as ecological models. Other models include the Social Area Analysis and Factorial Ecology (figure I). Some of the models are not so general; however they deal with certain urban attributes. Wingo's (1961) and Alonso's (1964), land use models are micro-economic models of urban land values. Central to this study are those attempts, which endeavor to categorize settings according to their capacity to affect the behavior of their indwellers.

This effort to unravel "person-environmental fit", according to Rapoport (1977), makes up the nitty-gritty of the environmental approach to urban form. Caplan (1983) believes that occupants will find fulfillment if vicinities are planned and built with respect to their expectations as expressed in the socio-cultural and physical elements of housing areas. Rapoport (1977) noted individual expectation to attain contentment which is derived culturally. Fried and Gleicher (1961) emphasized the significance of psychological and emotional attachment of occupants to their local area. They identified kinship ties, neighbor relationships, sectionalism in tight inter-personal associations, and solidity of period, assessment of the local area as a home and sense of uniformity with local areas as powerful elements influencing occupants' contentment.

It can be seen from the preceding literature and conceptual issues that spatial arrangement has a large task to come up with certain residential layouts which will satisfy dwellers' needs in terms of socio-economic and cultural anticipations. This would encompass 
steady alteration of proven principles, concepts and models of residential area planning and will, certainly, present a great deal of challenge but will be based on principles of planning with the residents.

\section{Figure 1: Three Generalization of Urban Structure (upper left: Burgess' Concentric Model; upper right}



Hoyt's Sector Model; bottom left: Harris and Ullman Multiple Nuclei Model)

Source: Department of Geography and Earth Sciences, University of North Carolina at Charlotte.

\section{Study Area}

Ondo town is one of the prominent urban centers in Ondo state, Southwestern Nigeria. The town is located on latitude $7^{0} 6^{\prime} 0.0180^{\prime \prime} \mathrm{N}$ and longitude $4^{0} 50^{\prime} 30.0984$ ' $\mathrm{E}$. The town is bounded to the north by Oluji/Okeigbo local government, to the east by Idanre local government, to the west and south by Odigbo local government. The population projection of the town stood at 389,900 during the 2006 population census. Ondo falls within the tropical wet and dry climate with a relatively small dry season. Consequently, rainfall in Ondo is seasonal in character with well-marked rainy and dry seasons (Yoade, Adeyemi and Onifade, 2018). 
The dry season comes between November and February, while the rainy season lasts for 8 months; from March to October; the mean annual rainfall is about 1,561 mm, the annual mean temperature is $27^{\circ} \mathrm{C}$, with a maximum of $30^{\circ} \mathrm{C}$. Ondo landscape is made up of generally undulating hills of granite outcrop of igneous origin, and is marked by few dome-shaped hills. These hills are found to be developed over the basement complex of metamorphic rocks with their summits ranging between 250 and 500 meters above sea level (Yoade et. al., 2018). The town has no major river; rather it is drained by several streams with fairly wide flood plains. The most important of these streams are Luwa, Lisaluwa, and Mode. The town falls within the moist/wet lowland forest, i.e. it has thick forested vegetation, but due to human activities, most of these original forests have been replaced with secondary re-growth such as post extraction secondary forests and post-abandoned secondary forests.

Figure 2: Map of the Study Area

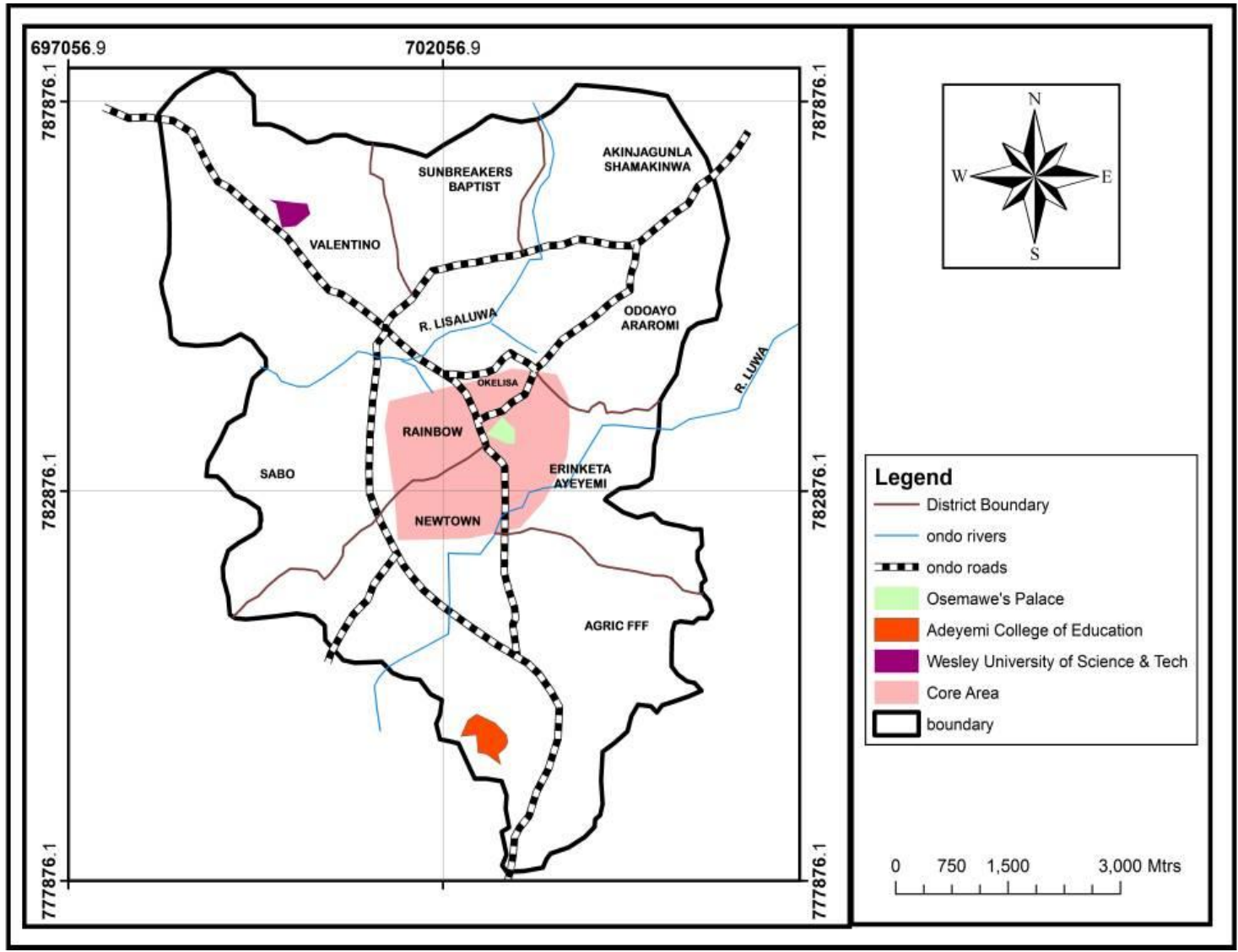

Source: Ondo West Town Planning Office 


\section{Research Method}

Data for the study were obtained from both primary and secondary sources. There are twelve (12) political wards in the study area out of which five (5) political wards fall under the core areas. However, three wards were selected and these political wards become the sample frame. Systematic sampling technique was used in selecting residents to be sampled. The first building was chosen randomly, subsequent unit of investigation was every $10^{\text {th }}$ residential building in each ward. The study administered structured questionnaire on the household head in each of the sampled buildings. Therefore, a total of 196 copies of questionnaires were administered out of which all copies were retrieved for the study. Information was obtained on residents' socio-economic background and residential quality of the study area. Sources of secondary data included maps from Planning Office, journals, conference proceedings, unpublished thesis and books. Data collected were analyzed using Statistical Package for the Social Sciences (SPSS) version 23. Also, both descriptive and inferential tools were used to analyze the data collected.

\section{Result and Discussion}

\section{A. Socio-Economic Characteristics of the Respondents}

Findings revealed that $23.5 \%$ of the respondents have tertiary education, $32.1 \%$ of the respondents claimed to have secondary certificate, $16.3 \%$ of the respondents are leaving school certificate holders, while $28.1 \%$ of the respondents have no education at all. Information on occupation revealed that; $31.6 \%$ of the respondents are business men and women, $29.6 \%$ are private sector, $20.9 \%$ are artisans, $4.1 \%$ are public servants, $3.1 \%$ are schooling, while the remaining $10.7 \%$ is for people without occupation in the study area.

Findings revealed that close to half(46.4\%) of the respondents had $2-5$ members in their households followed by $44.4 \%$ of the residents with 6-10 household members while $9.2 \%$ of the residents have 10 and above as household members. However, it also revealed that $65.8 \%$ of the respondents earn $\$ 20,000$ to $\$ 50,000,23.0 \%$ earn less than $\$ 20,000$ and $11.2 \%$ earn $\$ 50,000$ to $\$ 100,000$. It is possible that occupation, income and household size could have some effects on physical and environmental characteristics in the study area. It is also apparent from the result of the findings that most of the residents have lived in the study area for a period of time to be able to give useful information on the residential quality of the neighbourhood (Table I). 
Table 1: Socio-Economic Characteristics of the Respondents

\begin{tabular}{|c|c|c|}
\hline Socio-economic characteristics & Number & Percentage \\
\hline \multicolumn{3}{|c|}{ Level of education } \\
\hline Not educated & 55 & 28.1 \\
\hline Primary school & 32 & 16.3 \\
\hline Secondary school & 63 & 32.1 \\
\hline Tertiary school & 46 & 23.5 \\
\hline \multicolumn{3}{|c|}{ Occupation } \\
\hline Schooling & 6 & 3.1 \\
\hline Private sector & 58 & 29.6 \\
\hline Public sector & 8 & 4.1 \\
\hline Trading & 62 & 31.6 \\
\hline Artisanship & 41 & 20.9 \\
\hline None & 21 & 10.7 \\
\hline \multicolumn{3}{|c|}{ Household size } \\
\hline $2-5$ & 91 & 46.4 \\
\hline 6-10 & 87 & 44.4 \\
\hline 10 and above & 18 & 9.2 \\
\hline \multicolumn{3}{|c|}{ Monthly income } \\
\hline Less than $\$ 20,000$ & 45 & 23.0 \\
\hline$\$ 20,000-\$ 50,000$ & 129 & 65.8 \\
\hline$\$ 50,000-\$ 100,000$ & 22 & 11.2 \\
\hline \multicolumn{3}{|c|}{ Number of years spent in the study area } \\
\hline 1-10 & 09 & 4.6 \\
\hline 11-20 & 12 & 6.1 \\
\hline 21-30 & 30 & 15.3 \\
\hline $31-40$ & 45 & 23.0 \\
\hline 41-50 & 86 & 43.9 \\
\hline 50 and above & 14 & 7.1 \\
\hline Total & 196 & 100.0 \\
\hline
\end{tabular}

Source: Authors' Field Work, 2017

\section{B. Building/Infrastructural facilities}

The physical condition of the study area was poor. This is because the study area was in the old residential neighbourhood. Findings revealed that, majority $(61.8 \%)$ of the respondents live in "face-to -face" tenement building and the remaining 38.8\% lives in block of flats. As shown in Table 2, 69.4\% of buildings were constructed with cement blocks, $29.6 \%$ with mud and $1.0 \%$ with bricks. Also, findings established that majority of the respondents $(62.8 \%)$ used corrugated iron sheet for roofing, 35.2\% used asbestos while just $2.0 \%$ are with decking. Various methods of waste disposal employed by residents of the core area of Ondo city are illustrated in table 2 below. Majority of the respondents (62.8\%) disposed of their refuse using the waste collector of the Local Government, 24.0\% practiced burning of refuse, while only $13.3 \%$ of the residents dump refuse into run-off water. The 
study however revealed that majority of the respondents (58.2\%) use pit latrine while $41.8 \%$ of the respondents use water closet. The predominance of houses with corrugated iron sheet and the use of pit latrine are due partly to the economic status of the owners of the building who could not afford the cost of modern building materials. The implication is that most of the buildings in the area are old and in bad state and therefore there is need for rehabilitation and redevelopment of the area to make it conducive for living and working. Findings on water sources in the area established that majority (78.1\%) of the respondents had access to well water, $16.3 \%$ had access to borehole water while $5.6 \%$ had access to vendor water as the case may be. However, the result of road quality in the area revealed that majority (57.7\%) of the respondents believed that their road condition is poor, $36.7 \%$ said the road is fair while the remaining 5.6\% said that road condition in the study area is good. On level of accessibility to electricity, most (93.8\%) of the respondents had access to electricity while just $6.2 \%$ of the respondents did not have access to electricity in the area (Table II).

Table 2: Building/Infrastructural facilities

\begin{tabular}{|l|c|c|}
\hline \multicolumn{1}{|c|}{ Variables } & Number & Percentage \\
\hline \multicolumn{3}{|c|}{ Type house } \\
\hline Face-to-face & 120 & 61.8 \\
\hline Block of flats & 76 & 38.8 \\
\hline Total & 196 & 100.0 \\
\hline Cement block & 136 & 69.4 \\
\hline Brick & 2 & 1.0 \\
\hline Mud & 58 & 29.6 \\
\hline Total & 196 & 100.0 \\
\hline \multicolumn{3}{|c|}{ Roofing materials } \\
\hline Aluminum & 0 & 0 \\
\hline Asbestos & 69 & 35.2 \\
\hline Corrugated iron sheet & 123 & 62.8 \\
\hline Others & 4 & 2.0 \\
\hline Total & 196 & 100.0 \\
\hline \multicolumn{2}{|c|}{ Waste disposal } \\
\hline Open burning & 47 & 24.0 \\
\hline Waste collector & 123 & 62.8 \\
\hline $\begin{array}{l}\text { Dumping into run-off } \\
\text { water }\end{array}$ & 26 & 13.3 \\
\hline Total & 196 & 100.0 \\
\hline \multicolumn{2}{|c|}{} \\
\hline Open drainage & 131 & 66.8 \\
\hline Closed drainage & 12 & 6.1 \\
\hline None & 53 & 27.0 \\
\hline Total & 196 & 100.0 \\
\hline \multicolumn{2}{|c|}{ Drainage system } \\
\hline
\end{tabular}




\begin{tabular}{|l|c|c|}
\hline \multicolumn{3}{|c|}{ Toilet facilities } \\
\hline Pit latrine & 114 & 58.2 \\
\hline Water closet & 82 & 41.8 \\
\hline \multicolumn{3}{|c|}{ Water supply } \\
\hline Borehole & 153 & 78.1 \\
\hline Well & 32 & 16.3 \\
\hline Vendor & 11 & 5.6 \\
\hline \multicolumn{3}{|c|}{ Condition of roads } \\
\hline Good & 11 & 5.6 \\
\hline Fair & 72 & 36.7 \\
\hline Poor & 113 & 57.7 \\
\hline \multicolumn{2}{|c|}{ Electricity } \\
\hline Available & 184 & 93.8 \\
\hline Not available & - & - \\
\hline Disconnected & 12 & 6.2 \\
\hline \multicolumn{2}{|c|}{ Total } & $\mathbf{1 9 6}$ \\
\hline
\end{tabular}

Source: Authors' Field Work, 2017

\section{Level of satisfaction with residential quality}

The value of mean observed on the level of satisfaction is 3.48. The implication of this is that average of the respondents was satisfied despite the deplorable state of the area. Twelve (6.2\%) expressed total dissatisfaction on the existing housing situation in the study area. It can be deduced that despite the ugly nature of the area, majority of the respondents still feel satisfied with the study area (table III).Corroborating with the study of Jiboye (2010) and Yoade (2012), satisfaction with a home is not measured only by the facilities therein, or by quality of the dwelling per se; other intangible cultural and social factors come into the scale and this also reflected in the result of this study because majority of the respondent oppose resettlement to somewhere else in the implementation of the programme.

Table 3: Residents' satisfaction with residential quality

\begin{tabular}{|c|c|c|c|c|c|c|c|c|}
\hline & $\begin{array}{c}\text { Very } \\
\text { Satisfactory }\end{array}$ & $\begin{array}{c}\text { Moderately } \\
\text { satisfactory }\end{array}$ & $\begin{array}{c}\text { Slightly } \\
\text { satisfactory }\end{array}$ & Indifferent & $\begin{array}{c}\text { Not } \\
\text { satisfactory }\end{array}$ & Total & Mean & $\begin{array}{c}\text { Standard } \\
\text { deviation }\end{array}$ \\
\hline Frequency & 44 & 51 & 68 & 21 & 12 & 196 & 3.48 & 1.49 \\
\hline Percentage & 22.4 & 26.0 & 34.7 & 10.7 & 6.2 & $100 \%$ & & \\
\hline
\end{tabular}

Source: Field Survey, 2017

\section{Factors influencing residents' attachment to the area}

In order to determine factors influencing residents' attachment to the area, respondents were provided with a list of socio-cultural, physical and environmental variables identified in the literature. They were further instructed to kindly indicate level of importance of likely factors that cause their attachment to the study area. Respondents were to express their opinions using one of the five Likert scales of very significant (VS) 'significant' (S); 'Indifferent' (I), 'Insignificant' (IS) and "very insignificant" (VI).The analyses of the ratings 
indicated by the respondents from the Liker's scales adopted evolved into an index called "Significance Level" (SL).To arrive at SL, weight value of 1, 2, 3, 4 and 5 were respectively attached to very Insignificant, Insignificant'; 'Indifferent', Significant' and "Very Significant". The index for each factor was arrived at by dividing the Summation of Rating Value (SRV) by the total number of responses. The SRV for each factor was obtained through the addition of the product of the number of responses to each factor and the respective weight value attached to each rating.

Findings revealed that neighbourhood interactions were perceived to be most important factors influencing residents' attachment to the study area. Other factors that also ranked high include "family ties", "economic opportunities", "access to work place", "and "safety". Findings established that respondents place high value on socio-cultural values even above economic factors. Findings showed that most of the respondents were attached to the inner-city and this can be attributed to the cultural values and historical antecedents attached to the area.

In line with the findings of Onibokun (1985), Jiboye (2009) and Yoade et al. (2013), cultural values such as kingship and social relations were leading predictors of residential quality in the study area followed closely by religious consideration. Factors deemed less important include "access to water supply", "proximity to health facility" and "electricity supply" in rank order.

Table 4: Factors influencing residents' attachment to the area

\begin{tabular}{|c|c|c|c|c|c|c|c|}
\hline $\begin{array}{c}\text { Physical/ Environmental } \\
\text { /Socio-cultural Attributes }\end{array}$ & $\begin{array}{c}\text { VI } \\
(\boldsymbol{\%})\end{array}$ & $\begin{array}{c}\mathbf{I} \\
(\boldsymbol{\%})\end{array}$ & $\begin{array}{c}\mathbf{I} \\
(\boldsymbol{\%})\end{array}$ & $\begin{array}{c}\mathbf{S} \\
(\boldsymbol{\%})\end{array}$ & $\begin{array}{c}\text { VS } \\
(\boldsymbol{\%})\end{array}$ & $\begin{array}{c}\text { Mean } \\
\text { Score }\end{array}$ & Rank \\
\hline Historical antecedent & 7 & 18 & 9 & 33 & 129 & 4.32 & 3 \\
\hline Access to compound hall & 32 & 22 & 9 & 7 & 126 & 3.88 & 13 \\
\hline $\begin{array}{c}\text { Access to waste disposal } \\
\text { facility }\end{array}$ & 15 & 40 & 33 & 0 & 108 & 3.74 & 15 \\
\hline Economic opportunities & 3 & 6 & 66 & 24 & 97 & 4.10 & 9 \\
\hline $\begin{array}{c}\text { Proximity to schools } \\
\text { Neighbourhood interactions }\end{array}$ & 17 & 2 & 5 & 84 & 88 & 4.14 & 7 \\
\hline Proximity to work place & 22 & 0 & 1 & 45 & 128 & 4.31 & 4 \\
\hline Access to family house & 20 & 11 & 2 & 69 & 94 & 4.11 & 8 \\
\hline
\end{tabular}




\begin{tabular}{|c|c|c|c|c|c|c|c|}
\hline $\begin{array}{l}\text { Access to communities } \\
\text { amenities and facilities }\end{array}$ & 0 & 29 & 33 & 14 & 120 & 4.16 & 6 \\
\hline Safety & 13 & 28 & 4 & 6 & 145 & 4.23 & 5 \\
\hline $\begin{array}{l}\text { Access to water } \\
\text { supply }\end{array}$ & 39 & 14 & 27 & 18 & 98 & 3.62 & 16 \\
\hline Access to traditional market & 3 & 19 & 22 & 64 & 88 & 4.09 & 10 \\
\hline Electricity supply & 24 & 13 & 15 & 8 & 136 & 3.50 & 18 \\
\hline Access to transport network & 22 & 14 & 33 & 19 & 108 & 3.90 & 12 \\
\hline Proximity to health facility & 19 & 41 & 26 & 33 & 77 & 3.55 & 17 \\
\hline $\begin{array}{c}\text { Proximity to recreational } \\
\text { facilities }\end{array}$ & 18 & 35 & 14 & 29 & 100 & 3.80 & 14 \\
\hline Proximity to religious center & 23 & 15 & 19 & 36 & 103 & 3.92 & 11 \\
\hline
\end{tabular}

Source: Field Survey, 2017

\section{Discussions}

The situation in the city of Ondo illustrates the typical housing and environmental problems plaguing most of the large indigenous urban centers in the underdeveloped countries of Asia, Africa and Latin America. The major problem of the inner-city of Ondo town is structural deficiency and the drainage system is not properly channeled to enhance free flow of erosion. This in-turn leads to collapse of many buildings in the study area, while some are still facing such challenges. Also, another major feature that justifies urban renewal in a core area is the deplorable condition of the buildings, if the buildings that make up an area are regarded to be unfit for human habitations or at worse the demolition of such structures. The availability of basic infrastructure is also a point to be considered. As expected, most of the sampled residents of the study area have been living in the area long ago. Age has a significant impact on the structural condition of a building, this is because building becomes obsolete and worn-out after many years due to wear and tear on its parts. Characteristically, buildings in the core areas of any city are expected to be the oldest in the settlement.

Housing is more than shelter, if all necessary convenience that could allow for comfortable living is provided within. This is because the provision of infrastructures must definitely mean housing habitability. The necessary housing infrastructures include water, 
electricity, kitchen, toilet and bathroom, among others. The results indicate that the quality of some of these facilities in certain parts of the urban areas is generally poor. This finding supports those of (Jiboye, 2009; Owoeye and Omole, 2012; Buys and Miller, 2012), indicating the deplorable housing situations in most urban centers in developing nations. The finding also underscores the need for the improvement of the overall housing environment through large scale adjustment, effective urban management strategies and provision of basic infrastructures.

Considering the results of these findings, the level of interaction among the residents in most core areas in Nigeria has been relatively good. This is attributed to the socio-cultural background of most residents in which the spirit of neighborliness is embraced, regardless of the morphology of the area. When the analysis of this result was done along the line of the core political wards, it was observed that the pattern of neighborhoods' interaction among the residents was similar with the aggregated figures discussed above. Corroborating the study of Onibokun (1972), Gyuse (1974), Owoeye and Sogbon (2012b) and Yoade et al. (2013), the preservation of the historic core, which provides future generations with stimulating ideas from their cultural heritage, is essential for the development of modern cities. They considered the historic core of a city as the "collective memory of the population", where old buildings, monuments, parks, and neighborhoods, as well as the old pattern of the city which gives the city its unique character are necessary to maintain the city's vitality. Therefore, present, past, and future histories are all equally important in the making of a modern city.

\section{Conclusion and Recommendations}

The inhabitants of the core areas are steeped in tradition, seemingly conservative, and unaware of the magnitude and dimensions of the housing and environmental problems. The immediate task, then, is the activation of these inhabitants. Activation of the senses embraces the emergence of citizens who will be aware of their environmental problems, who will believe changes are not only possible but feasible, and who will have a keen desire to change and accept changes. The study concluded that residents of the inner-city were attached to tradition, seemingly conservative, and unaware of the magnitude and dimensions of the housing and environmental problems around them. To prevent further deterioration/decay and avoid breakdown of epidemics in the study area, there is therefore need to improve on the quality of the residential areas through strategies tailored especially to the physical and environmental quality of the inner city. 
The study therefore recommends the involvement of residents in the provision of relevant information for policy and programme interventions by stakeholders which will go a long way in fashioning interventions that truly respond to the needs and expectations of the people. It is necessary to take into consideration their social, economic and technical endowments and requirements. Also, there is need to increase income earning opportunities for households in informal settlements, especially for the aged who constitute a significant proportion of household heads in study area. In summary, slum upgrading and redevelopment as urban renewal strategies should be explored to improve residential quality in the inner city of Sub-Sahara Africa

\section{References}

Adedeji, Y.M.D. (2008). Sustainable Housing for Low-Income Industrial Workers in IkejaIlupeju Estate: Materials Initiative Options; A PhD Research Thesis, Department of Architecture, Federal University of Technology, Akure.

Afon, A. (2000). Use of Residents Environment Quality Indicator (EQI) Data in a residential Housing improvement, In Effective Housing in the 21st century, Nigeria. The Environmental Forum, F.U.T.A pp.115-122.

Agbola T. (1998). Sustainable Approach to Slum Prevention in Nigeria: Opportunities, Challenges and Strategies", Keynote paper presented at the Second House of Representativesee Committee on Habitat: "Sustainable Slum Upgrading in Urban Areas", Abuja, 25-27 October.

Alonso, W. (1964). Location and Land Use. Harvard University Press (Massachusetts)

Arimah, B. C. and Adeagbo, D. (2000). Compliance with urban development and planning regulations in Ibadan, Nigeria. Habitat International, 24(3), 279-294.

Awolusi, O. and Jegede, A. (2013). Challenges of Sustainability and Urban Development: A Case of Ado-Ekiti State, Nigeria International Education Research Vol. I, Issue 122 29

Buys, L. and Miller, E. (2012). Residential satisfaction in inner urban higher-density Brisbane, Australia: role of dwelling design, neighbourhood and neighbours. Journal of Environmental Planning and Management, 55(3), 319-338.

Caplan, R. D. (1983). Person-environment fit: Past, present, and future. In C. Cooper (Ed.), Stress research: New directions for the 1980s (pp. 35-78). London: Wiley.

Cities Alliance. (2013). A Policy Framework for a Slum Upgrading Programme. Retrieved June 24, 2013, from http://www.citiesalliance.org/su-policy

Dimuna, K.O. and Omatsone, M.E. (2010). Regeneration in the Nigerian urban built environment, Journal of Human Ecology, 29(2). 141-149. 
Ebong, M. (1983). The Perception of Residential Quality: A case study of Calabar, Nigeria. Third World Planning Review, 5(3):273-284.

Fourchard, L. Albert, O. and Agbola, T. (2003). Security, Segregation and Social Networks in West African Cities, IFRA, Ibadan.

FRN (2013). Nigeria over 167million population: Implications and Challenges, National Population Commission, Abuja.

Greed, C. (2011). Planning for sustainable urban areas or everyday life and inclusion. Urban Design and Planning, 164 (2). pp. 107-119.

Gyuse, T.T.I. (1974). Cultural Principles for Tiv Housing Form in Settlement Context MPD, (Thesis) Faculty of Environmental Design, University of Calgary, 1974

Harvey (2000). "Urban Land Economics" Palgrave Macmillan, Fifth Edition pp. 256-257.

In: Albert, I. O. et al (Eds.) Urban Management and Urban Violence in Africa. Ibadan: IFRA, pp. 119-131.

H.D.R (2004). "List of Countries by Human Development Index" the 2003 Human Development Report, U.N.D.P., Washington DC.

Jagun, A. (1983). "Urban Housing Need Estimate in Nigeria: Governmental Capability in It's Provision" Journal of Business and Social Studies, 4 (2)

Jeffrey, P. and Pounder, J. (2004). Physical and environmental aspect in Urban Regeneration a Handbook edited by Robert, P \& Sykes, H. Sage publication, Delhi, 2004.

Jiboye, A. D. (2009). "The Relevance of House-form to Housing Quality in Nigeria". International Journal of Sustainable Development. Vol. 2, No. 3, 2009c. pp. 29-36.

Jiboye, A.D. (2010). Evaluating the Pattern of Residential Quality in Nigeria: The Case of Osogbo Township, Series: Architecture and Civil Engineering Vol. 8, No 3, 2010, pp. 307 - 316, DOI: 10.2298/FUACE1003307J

Mabogunje, A.L. (1980). The Development Process: A Spatial Perspective (2nd Edition) London: Unwin Hayman Ltd

Mabogunje, A.L. (2002). Nigerian and the Good Urban Governance Campaign, The Launching of the Global Campaign for Good Urban Governance in Nigeria. Federal Ministry of Works and Housing, Abuja, Nigeria.

Olotuah, A. O. (2005). "Sustainable Urban Housing Provision in Nigeria: A Critical Assessment of Development Options" Proceedings of the Africa Union of Architects Congress, Abuja, 23-28 May, 64-74

Onibokun, A.G. (1972). Nigeria: Strategies for Core Area Redevelopment In Sub-Sahara Africa: Journal of the Royal Town Planning Institute 58(2).

Onibokun, A.G. (1985). "The Future of Physical and Administration in Nigeria". "National Workshop on Development Control and Planning Administration in Nigeria”.NISER, Ibadan.P6-15. 
Pakistan Journal of Humanities and Social Sciences, 6(2), 2018

Onibokun, A.G. (1986). Urban Growth and Urban Management in Nigeria with Particular Reference to Public Utilities and Infrastructure. NISER Ibadan.

Osuide S.O. and Dimuna, K.O. (2005). Effects of Population Growth on Urbanization and the Environment in Nigeria. pp. 27-33. In: Proceeding of year 2000 National Seminar on Population, Growth, Architecture and the Environment. Osuide SO (Ed.).Rasjel Publishers.

Owoeye, J.O and Omole, F.K (2012). Built Environment Decay and Health Situation of Slum

Dwellers in Residential Cores of Akure, Nigeria. America Journal of Human Ecology; 1(2): 33-39

Owoeye, J. and Sogbon, O (2012a). Reducing the Environmental Health-Risk of Vulnerable Group in High-Density District of Akure, Nigeria; Academic Journal of Interdisciplinary Studies - Mediterranean Center of Social and Educational Research; Rome Italy; 1(2): 123-135; http://www.doi:IO.590I/ajis.2012.vIn2p123

Owoeye, J. and Sogbon, O. (2012b). Socio-cultural Lifestyle of Slum Dwellers - A Limiting Factor to Urban Renewal Efforts in Akure, Nigeria; Journal of the Environment, Federal University of Technology, Yola; 1(1): 34-42; http://dx.doi.org/10.4314/fje.v6i2.8

Oyeleye, I. (2013). Challenges of Urbanization and Urban Growth in Nigeria. American Journal of Sustainable Cities and society Issue 2, Vol.1. Available online on http://www.rspublication.com/ajscs.html

Tomori, M. A. (2012). Transformation of Ibadan built environment through restoration of urban Infrastructure and efficient service delivery. Available http://macosconsultancy.com/Publication/Transformation\%20of\%20Ibadan\%20Built \%20Environment.pdf

UNDESA (2012). World Urbanization Prospects: The 2011 Revision, United Nations Departments of Economic and Social Affairs (UNDESA), Population Division, April 2011.

UNFPA (1993).United Nations report on the state of the world environment from 1972 to 1992.

Un-Habitat (2003).Facing the slum Challenge; Global Advanced Draft Report on Human Settlements, Nairobi.

UN-Habitat (2012). The state of the world's cities 2012/2013. Property of cities, World Urban Forum Edition. United National Human Settlements Programme, Nairobi, Kenya.

United Nations (2013). Over 200 million escape slums but overall number still rising, UN report finds. UN News Centre, New York. Retrieved June 24, 2013, from http://www.un.org/apps/news/story.asp?NewsID=34119\& 
Wingo, L. (1961). Transportation and Urban Land. John Hopkins Press (Baltimore)

World Bank (2014). International Development Association Project Appraisal Document for the Ibadan Urban Flood Management Project (IUFMP). Report No: PAD687.

World Bank (2013). Sub-Saharan Africa: Development only. Retrieved from http://data.worldbank.org/region/sub-saharan-africa

Yoade and Fatusin, A.F. (2016). Inner City Decay and Rehabilitation in Ile-Ife, Nigeria; Lagos Journal of Environmental studies Vol. 8 (No 2)

Yoade, A., Adeyemi, S., and Onifade, V. (2018). Perception of Environmental Quality in Ondo, Nigeria; Journal of Environmental Design, University of Uyo, Akwa-Ibom State, Nigeria; Volume 2, Issue 1, pp. 10-18; March, 2018.

Yoade, A.O.; Olayiwola, L.M., and Popoola, K.O. (2013).Socio-cultural Challenges to Urban Renewal in Ile-Ife, Nigeria, Volume 2, Issue 1, pp. 10-18; March, 2013; Online Journal of African Affairs, 2013 Online Research Journals.

Zhai, B., and Ng, M. K. (2013). Urban regeneration and social capital in China: A case study of the Drum Tower Muslim District in Xi'an. Cities, 35, 14-25. http://dx.doi.org/10.1016/j.cities.2013.05.003 